\title{
In vitro regeneration techniques in the grass pea (Lathyrus sativus L.)
} plant

\author{
Muhammed İkbal Çatal ${ }^{1 *}$, Adil Bakoğlu ${ }^{2}$ \\ ${ }^{1 *}$ Department of Field Crops, Faculty of Agriculture and Natural Sciences, Recep Tayyip Erdoğan University, Rize, \\ Turkey \\ ${ }^{2}$ Department of Plant and Animal Production, Vocational School of Pazar, Recep Tayyip Erdoğan University, Rize, \\ Turkey \\ Corresponding author: muhammed.catal@erdogan.edu.tr
}

\begin{abstract}
The Lathyrus genus is in the legumes family with annual or perennial species number of 160 . There are 58 species naturally grown in Turkey, 18 of them are endemic. In Rize province, 8 species were identified, 2 of them were endemic. In the world, Lathyrus species are evaluated in the animal feed as green grass, hay and grain feed, fertilization of soil as a green manure plant and human nutrition as food grain legume plant. The cultivation of Lathyrus species are very rare in our country and are generally used in animal feeding and in small quantities in human nutrition. Grass pea (Lathyrus sativus L.) plant is the most used species in the world, because it is resistant to adverse soil conditions, drought and flooding. Various tissue culture methods are used to develop and reproduce this species. Plant tissue culture is being applied both in the development of new varieties and genetic changes in existing varieties, and in the production of species which are difficult to reproduce and protect of the disappearing species. The basic system used in plant tissue culture processes and genetic improvements is plant regeneration. In this review, some studies related to the in vitro regeneration techniques of the grass pea plants have been put together and the techniques used in regeneration have been evaluated.
\end{abstract}

Keywords: Grass pea, Lathyrus sativus, in vitro, regeneration techniques

Özet

Lathyrus cinsi, tek veya çok yıllık 160 tür sayısı ile baklagiller familyasında yer almaktadır. Türkiye'de 18'i endemik olmak üzere 58 tür doğal olarak yetişmektedir. Rize ilinde ise 2'si endemik olmak üzere 8 tür tespit edilmiştir. Lathyrus türleri dünyada yeşil ot, kuru ot ve tane yem olarak hayvan beslemede, yeşil gübre bitkisi olarak toprağın yapısını iyileştirmede ve yemeklik tane baklagil bitkisi olarak insan beslenmesinde değerlendirilmektedir. Lathyrus türlerinin tarımı ülkemizde çok az yapılmakta ve genellikle hayvan beslenmesinde ve az miktarda da insan beslenmesinde kullanılmaktadır. Yaygın mürdümük (Lathyrus sativus L.) bitkisi, olumsuz toprak koşullarına, kuraklığa ve su basmalarına dayanıklı olması nedeniyle dünyada en fazla yetiştirilen türdür. Bu türü geliştirmek ve çoğaltmak amacıyla çeşitli doku kültürü yöntemleri kullanılmaktadır. Bitki doku kültürü, yeni çeşit geliştirmek ve var olan çeşitlerde genetik değişim oluşturmak, kaybolmakta olan türlerin korunması ve çoğaltılması zor olan türlerin üretiminde uygulanmaktadır. Bitki doku kültürü işlemlerinde ve genetik iyileştirmelerde kullanılan temel sistem bitki rejenerasyonudur. Bu derleme de mürdümük bitkisinin in vitro rejenerasyon teknikleri ile ilgili yapılıış bazı çalışmalar bir araya getirilmiş ve rejenerasyonda kullanılan teknikler değerlendirilmiş̧ir.

Anahtar Kelimeler: Mürdümük, Lathyrus sativus, in vitro, rejenerasyon teknikleri

\section{INTRODUCTION}

The Lathyrus genus is in the legumes (Fabaceae/Leguminoseae) family with annual or perennial species number of 160 (Plitmann et al.,1995). Grass pea species are naturally grown in every region of Turkey. Although the sources indicate that the grasspea species are mostly distributed in the Eastern and Southeastern Anatolia regions in our country, in recent research it has been determined that the species of grass pea in coastal and inland parts of Central Black Sea show very important spread and variability (Acar et al., 2001). Davis, 
(1970) found that there were 58 species naturally grown in Turkey, 18 of them are endemic; Genç and Şahin, (2001) found that there were 61 species. In the Black Sea Region vegetation approximately 20 species have been identified (Davis, 1970). It was determined that 8 Lathyrus species, 2 of them were endemic (L. aureus, L. tukhtensis-Endemic, L. pratensis, L. laxiflorus subsp. laxiflorus, L. czeczottianus-Endemic, L. roseus, $L$. rotundifolius subsp. miniatus, L. aphaca var. floribundus) were naturally grown in vegetation studies carried out in Rize province (Güner et al., 1987).

Lathyrus species are evaluated globally in animal nutrition (as green grass, hay and grain feed), in improving soil structure (as green manure plant) and in human nutrition (as legumes and vegetables for food). After Lathyrus species have been grazed in a certain period, seeds can also be obtained from growing plants when the grazing is interrupted. In our country, Lathyrus species are cultivated very little and are generally evaluated in animal nutrition and in small amount of human nutrition (Genç and Şahin, 2001).

There are some substances which have adverse effects on nutrition in the grass pea species (Urga et al., 1995). The most important of these is ODAP ( $\beta$-N-oxalyl-L- $\alpha, \beta$-diaminopropionic acid). Grass pea seeds usually lose their harmful effect when boiled and steamed (Gençkan, 1992).

The grass pea (Lathyrus sativus L.) plant from Lathyrus species is the most preferred species in the World, because it is resistant to adverse soil conditions, drought and flooding. Be resistant to these adverse conditions of grass pea plant and grow naturally in all parts of Turkey, it has made it important for our country to this plant. For this purpose, various tissue culture methods have been applied to develop and reproduce this species.

Plant tissue culture is being applied both in the development of new varieties and genetic changes in existing varieties, and in the production of species which are difficult to reproduce and protect of the disappearing species. The basic system used in plant tissue culture processes and genetic improvements is plant regeneration (Babaoğlu et al., 2002). In this review, some studies related to the in vitro regeneration techniques of the grass pea (Lathyrus sativus L.) plants have been put together and the techniques used in regeneration have been evaluated.

\section{PLANT REGENERATION TECHNIQUES}

In plant regeneration; organogenesis, somatic embryogenesis, protoplast culture, haploid cell culture and meristem culture (disease free plant production) techniques are used. The most common methods used in plant regeneration are direct or indirect organogenesis and somatic embryogenesis techniques. Here, we will focus on some studies on organogenesis and somatic embryogenesis, which using in vitro regeneration techniques that are made on the grass pea (Lathyrus sativus L.) plant.

\section{Organogenesis}

Organogenesis is a process, which leads to a structure depend on to the tissue of origin, the unipolar and vascular system called shoot or root primordium (draft) resulting in some change, that be applied pressure to cells and tissues (Gürel et al., 2002). Organogenesis is carried out in two ways, directly or indirectly. In organogenesis studies, stem, root, leaf, flower state, ovary or egg cell, seedling organs, cotyledon and hypocotyl and seed embryo as the explant are commonly used.

Barik et al., (2004) induced from cotyledonary nodes of grass pea (Lathyrus sativus L.) derived from 7-dayold in vitro seedlings. Among the five genotypes tested, shoot proliferation frequency was the highest (93.3\%) for IC-120487, giving the maximum number of shoots (11.3 shoots per explant) on MS medium augmented with $2.0 \mathrm{mg} \mathrm{l}^{-1} \mathrm{BA}$. Up to $81.8 \%$ of the shoots developed roots following transfer to half-strength MS medium containing $0.5 \mathrm{mg} \mathrm{l}^{-1}$ indole-3-acetic acid. Later, the same researcher Barik et al.,(2005) different explant types of the grass pea (Lathyrus sativus L.) tested epicotyl segments for high frequency plant regeneration were most responsive. Murashige and Skoog's (1962) medium augmented with $17.76 \mu \mathrm{M}$ 6-benzyladenine+10.74 $\mu \mathrm{M} \alpha$ 
-naphthaleneacetic acid showed the highest percentage of direct shoot regeneration. Among cultivars IC120487 showed the highest regeneration frequency $(80 \%)$ with maximum shoot numbers $(8.2$ shoots per explant) and maximum average shoot length $(4.1 \mathrm{~cm})$. About $78 \%$ of the regenerated shoots were rooted in half-strength MS medium containing $2.85 \mu \mathrm{M}$ indole-3-acetic acid. After primary hardening the plantlets were established in soil with a survival rate of $75 \%$.

Bainade et al., (2014) obtained from leaf segments of 10-15 days old seedling, which were used as explant and B5 basal media $+2.0 \mathrm{mg} / \mathrm{l} \mathrm{NAA}+0.5 \mathrm{mg} / \mathrm{l} \mathrm{BAP}$, was used for callus induction and differentiation. The leaf explant of Lathyrus cv. NLK- 40 exhibited $92 \%$ response to callusing and it took 30-32 days to produce full grown green compact callus. Afterwards, Saha et al., (2015) highest percentage of shoots were obtained at 4.0 $\mathrm{mg} / \mathrm{l}$ of BAP on nodal explants. Stunted multiple shoots were developed from nodal explants while $1.5 \mathrm{mg} / \mathrm{l}$ TDZ was used. About $56 \%$ of direct shoots were also obtained, while the combination of BAP (4.0 mg/l) and NAA $(0.5 \mathrm{mg} / \mathrm{l})$ were used. Regenerated plantlets were rooted most effectively $(40 \%)$ in rooting medium containing half strength of MS basal medium containing $1.0 \mathrm{mg} / \mathrm{l} \mathrm{NAA}$.

Li et al., (2016) in the present study, among explants, leaf segments were the high regeneration efficiency (i.e., $66.48 \%$ in L. sativus and $62.13 \%$ in L. cicera). When these in vitro derived plantlets of the two Lathyrus species were planted on half-strength Murashige and Skoog medium (MS) medium with $\alpha$-naphthaleneacetic acid (NAA) supplemented, $60 \%$ of them developed several roots. After being transplanted into soil, above $85 \%$ of each Lathyrus species grew well. Chakraborty et al., (2016) the maximum number of multiple shoot induction and proliferation (12 - 14 shoots /explant) was observed in cotyledonary node explant within 30 days using $1.5 \mathrm{mg} / \mathrm{l} \mathrm{BAP}$. The micro shoots were subcultured in the same media containing low concentration of IAA $(0.03 \mathrm{mg} / \mathrm{l})$ for further elongation. Up to $85 \%$ of shoots developed roots following their transfer to half strength of Murashige and Skoog media containing $0.25 \mathrm{mg} / \mathrm{l}$ indole-3-butyric acid (IBA) within 25 days. Rooted plantlets were successfully hardened unde culture conditions and were subsequently established in the greenhouse with survival rate of $85 \%$. The entire in vitro regeneration process took relatively short period of time (90-100 days). Thus, the present study remeined successful in developing a rapid and efficient in vitro regeneration through direct organogenesis of Lathyrus sativus for subsequent development of efficient transformation systems.

\section{Somatic embriyogenesis}

It is possible to obtain embryos from any somatic cell, tissue or organ of a plant, especially by adjusting the plant growth regulators in vitro culture conditions. The embryos developed from vegetative embryos are called somatic embryos. Somatic tissue cells are first cultured in medium containing high-level auxin (usually 2,4D), then acquired an ability to produce embryos if transferred to an oxine-free medium. Somatic embryogenesis can be used in clonal propagation, synthetic seed production and gene transfer. However, explant source, genotype, plant growth regulators, nitrogen source and environmental conditions are important factors affecting somatic embryogenesis. Somatic embryogenesis occurs directly and indirectly in two ways (Özcan et al., 2002).

Barna and Mehta, (1995) somatic embryogenesis was obtained from immature leaflets and nodal segments by using 2,4-D in the induction medium. Kendir at al., (2009) in the study used immature zygotic embriyos of grass pea (Lathyrus sativus L.), the TDZ (with ascorbic acid) was more potent for axillary shoot regeneration compared to BAP-NAA (with ascorbic acid) with the highest shoot regeneration on MS medium containing $0.45 \mathrm{mg} / \mathrm{l} \mathrm{TDZ}$. The best rooting was achieved on MS medium containing $0.90 \mathrm{mg} / \mathrm{l} \mathrm{NAA}$. 

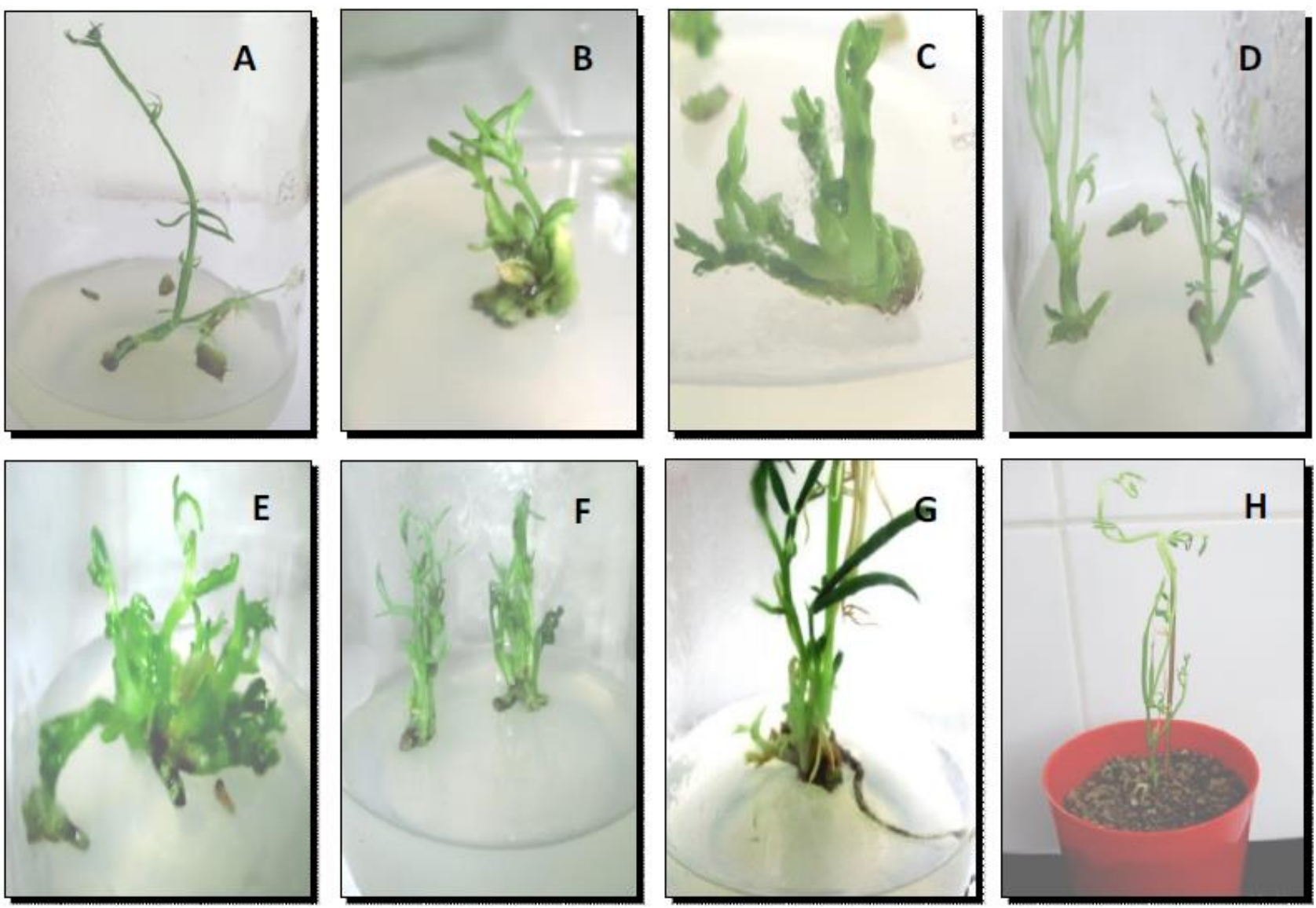

Figure 1. Shoot Regeneration of Grass pea. A-Direct shoot regenerated from nodal explant, B-Shoots regenerated from leaflet, C to D-Multiple shoots regenerated at high concentrations of BAP, E to F-Multiple shoots obtained on MS medium containing TDZ, G-Regenerated shoots rooted, H-Plantlets acclimatized and potted (Source: Saha et al., 2015).

Tripathy et al., (2013) internode explants of grass pea (Lathyrus sativus L.) pre-cultured in B5 with 2,4-D (2 $\mathrm{mg} / \mathrm{l})+\mathrm{BAP}(0.5 \mathrm{mg} / \mathrm{l})$ when transferred to BM medium containing $0.5 \mathrm{mg} / \mathrm{l} \mathrm{NAA}+2 \mathrm{mg} / \mathrm{l} \mathrm{BAP}$; produced conspicuous, glossy, dark green and well developed somatic embryos. Multiple shoots occasionally grew from such green calli on transfer to a shoot regenerating medium, B5+0.5 mg/l IAA+1 mg/l BAP. Dhenkanal local yielded the highest somatic embryogenic regeneration response $(19.8+1.32 \%)$ followed by Nirmal $(12.5+$ 1.66\%), while P24 did not respond at all. Thereafter, Piwowarczyk and Pindel, (2014), callus cultures from root explants of Lathyrus sativus L. 'Derek' were tested for their morphogenic capacity. Callus originally cultivated onmodified MS medium supplemented with $0.05 \mathrm{mg} \mathrm{L}^{-1}$ picloram, formed embryo-like structures upon transfer to media containing $0.1 \mathrm{mg} \mathrm{L}^{-1}$ picloram or $0.9 \mathrm{mg} \mathrm{L}^{-1}$ 2,4-D. Histological examinations confirmed embryogenity of obtained structures.

Sridhar et al. (2015) developed an efficient micropropagation protocol through somatic embryogenesis from leaf and intermodal explants of Lathyrus sativus. Murashigae-Skoog medium supplemented with 2,4-D (1.0 $\mathrm{mg} / \mathrm{l})$ and (BAP) benzylaminopurine $(5 \mathrm{mg} / \mathrm{l})$ resulted in the production of green embryogenenic callus with clearly differentiated somatic embryos with frequency of plant conversion rate from leaf and internode explants was $50 \pm 0.8$ and $53 \pm 0.5$ respectively. The regenerated shoot were rooted on root induction medium, transplanted to pots and later transferred to field. The survival percentage of the transplanted plants was $33 \pm 0.1$ for internode and $24 \pm 0.6$ for leaf explants. Bartepe et al., (2017) grass pea (Lathyrus sativus L.) using embryos with two cotyledons, the maximum shoot regeneration frequency of $89.80 \%$ and number of 15.83 shoots per explant was induced on MS medium containing $2 \mathrm{mg} / \mathrm{l} \mathrm{BAP}$ and $1 \mathrm{mg} / \mathrm{l} \mathrm{NAA}$. 


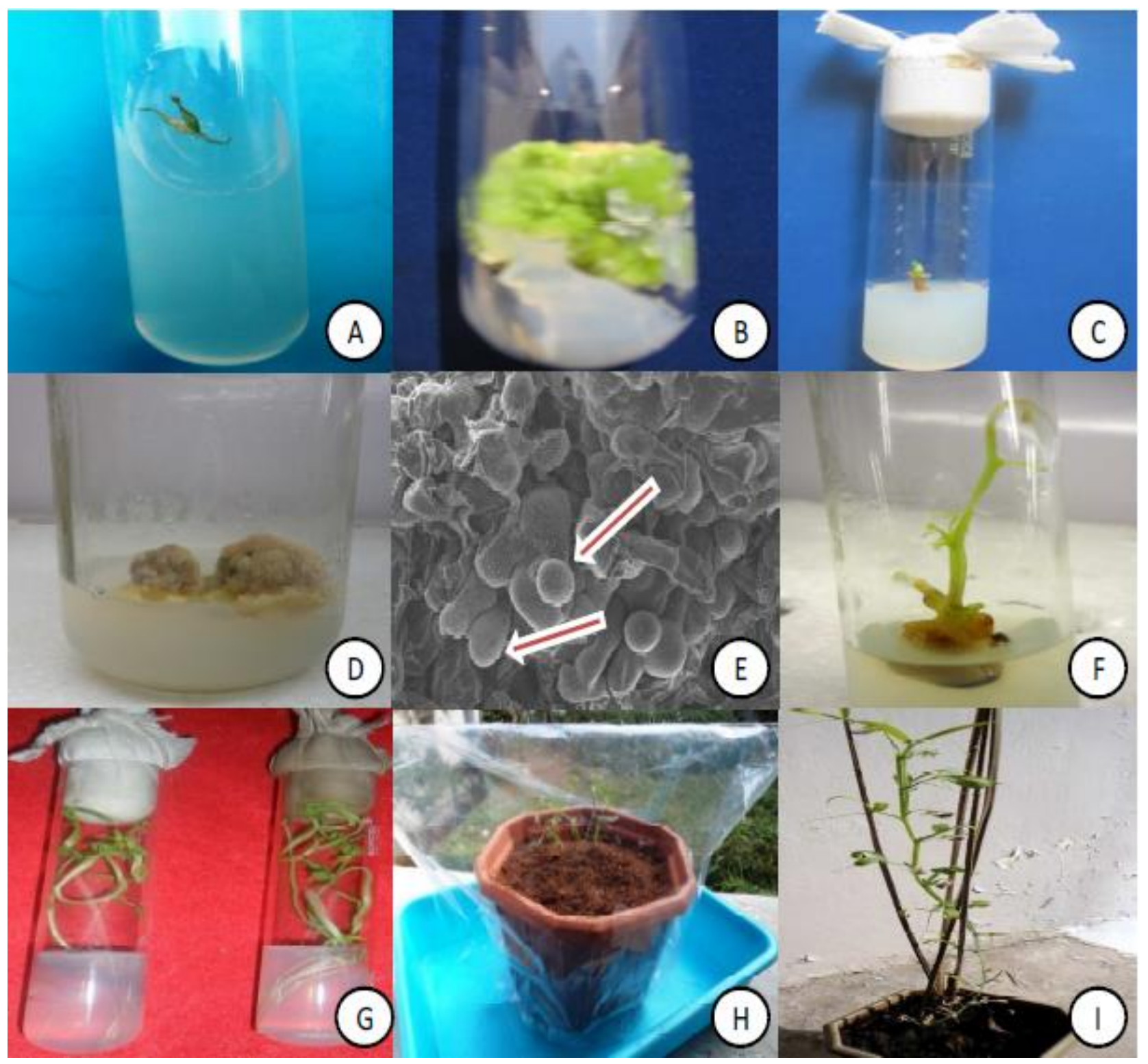

Figure 2. Somatic embryogenesis and plant regeneration from leaf and internode explants of Lathyrus sativus. (A) Leaf explant on medium-A (MS media supplemented with 2, 4-D $(0.5 \mathrm{mg} / \mathrm{L})$, BAP [0.5 mg/L], Glutamine [684.2 $\mu \mathrm{M}]$ and Citric acid $[520.5 \mu \mathrm{M}]$ ); (B) Proembryos from the embryogenic callus produced from the leaf explants; (C) internode on medium-A; (D) Proembryos from the embryogenic callus that was developed from internode explants. (E) Scanning electron microscope section showing heart shaped and oval shaped somatic embryos. (F) Plantlets of Lathyrus sativus converted from somatic embryos on medium-B (MS medium supplemented with BA [2 mg/l], Glu [684.2 $\mu \mathrm{M}$ ] and CA $[520.5 \mu \mathrm{M}]$ ); $(\mathrm{G})$ Well developed roots from the plantlets inoculated on root induction medium-C (Half strength MS supplemented with IBA $(2 \mathrm{mg} / \mathrm{l})$, Glu $[684.2 \mu \mathrm{M}]$ and CA [520.5 $\mu \mathrm{M}]$ ]; $(\mathrm{H})$ A plantlet transferred to pot and gradually acclimatized in the glasshouse before transfer to the botanical garden. (I) Well established plantlet in the glasshouse before it transferred to the botanical garden (Source: Sridhar et al., 2015).

As a result, it can be understood that direct or indirect organogenesis and somatic embryogenesis techniques can be used to in production the regenerate shoots and somatic embryos from different parts of the plant in vitro regeneration of the grass pea plant and successful protocols can be developed for this purpose. This situation can be evaluated both in development of breeding to low ODAP content varieties and in micropropogation to ensure rapid production of grass pea (Lathyrus sativus L.) plant resistant to adverse conditions. 


\section{Kaynaklar}

Acar, Z., Ayan, İ., Gülser, C., 2001. Some morphological and nutritional properties of legumes under natural conditions. Pakistan Journal of Biological Sciences, 4:11, 1312-1315.

Babaoğlu, M., Yorgancılar, M., Akbudak, M.A., 2002. Doku kültürü: Temel laboratuvar teknikleri, Bitki Biyoteknolojisi, Doku Kültürü ve Uygulamaları. Editörler: Babaoğlu, M., Gürel, E., Özcan, S. Konya, s.1-35.

Bainade, P. S., Patıl, S. R., Deshmukh, S. G. and Sawant, P. V., 2014. In Vitro Regeneration of Lathyrus (Lathyrus sattvus L.) As Influenced By Mutagen Treatment. Journal of Cell and Tissue Research Vol. 14(1) 4113-4116. ISSN: 0973-0028; E-ISSN: 0974-0910

Barik., D.P., Naik, S.K., Mohapatra, U. and Chand, P.K. 2004. High-Frequency Plant Regeneration By In Vitro Shoot ProlıferationIn Cotyledonary Node Explants Of Grasspea (Lathyrus satıvus L.). In Vitro Cell. Dev. Biol. Plant 40:467470.

Barik, D.P., Mohapatra, U. and Chand, P.K. 2005. High frequency in vitro regeneration of Lathyrus sativus L. Biologia Plantarum 49 (4): 637-639.

Barna, K.S. and Mehta, S.L., 1995. Genetic Transformation and Somatic Embryogenesis in Lathyrus sativus. J. Plant Biochemistry \& Biotechnology Vol. 4, 67-71.

Bartepe, S., Aasım, M., Özcan, S.F., Khawar, K.M. and Özcan, S., 2017. High Frequency Axıllary Shoots InductionIn Grass Pea (Lathyrus satıvus L.). Bangladesh J. Bot. 46(1): 119-124.

Chakraborty, S., Bhattacharyya, J., Manna, A., Sikdar, N., Chakraborty, A. and Pati, B.R., 2016. A Rapid and Efficient Protocol for In Vitro Plant Regeneration of Lathyrus sativus L. (Grass Pea) Through Multiple Shooting. International Journal of Current Research, Vol. 8, Issue 11, pp. 41556-41564.

Davis, P. H., 1970. Flora Of Turkey and East Aegean Islands. Edinburgh, 328-369.

Genç, H. and Şahin, A., 2001. Batı Akdeniz ve Güney Ege Bölgesinde yetişen Bazı Lathyrus L. türleri üzerinde sitotaksonomik araştırmalar. III. S.D.Ü. Fen Bilimleri Dergisi, 5:1, s. 98-112.

Gençkan, M.S., 1992. Yembitkileri Tarımı. Ege Üniversitesi Ziraat Fakültesi Yayınları 467, 249-254, Bornova-İzmir.

Güner, A., Vural, M., Sorkun, K., 1987. Rize Florası, Vejetasyonu ve Yöre Ballarının Polen Analizi. TÜBİTAK Matematik, Fizik ve Biyolojik Bilimler Araştırma Grubu, Proje No: TBAG-650, Ankara.

Gürel, E., Uçar, A., Türker, U., 2002. Organogenesis. Bitki Biyoteknolojisi, Doku Kültürü ve Uygulamaları. Editörler: Babaoğlu, M., Gürel, E., Özcan, S. Konya, s.36-70.

Kendir, H., Sahin-Demirbag, N., Khawar, K.M. and Özcan, S., 2009. In Vitro Plant Regeneration from Turkish Grasspea (Lathyrus Sativus L.) Using Immature Zygotic Embryo Explant. Biotechnology \& Biotechnological Equipment, 23:2, 1177-1180.

Li, R.S., Tao, Y.J., Liu, F.J., Hu, X., Xu, Q.L., Li, K.Y., 2016. In vitro plant regeneration via indirect organogenesis from different explantsof Lathyrus sativus L. and Lathyrus cicera L. International Journal of Experimental Botany FYTON 85: 87-93 - ISSN 00319457

Murashige, T., Skoog, F., 1962. A revised medium for rapid growth and bioassayswith tobacco tissue cultures. Physiol. Plant. 15: 472-497. 
Özcan, S., Babaoğlu, M., Sancak, C., 2002. Somatik embriyogenesis. Doku Kültürü ve Uygulamaları. Editörler: Babaoğlu, M., Gürel, E., Özcan, S. Konya, s. 71-88.

Piwowarczyk, B. and Pindel, A., 2014. Early stages of somatic embryogenesis in rootcallus of grasspea (Lathyrus sativus L.). Journal of Central European Agriculture, 15(3), p.209-218 DOI: 10.5513/JCEA01/15.3.1476.

Plitmann, U., Gabay, R. and Cohen, O., 1995. Innovations in the tribe Vicieae (Fabaceae) from Israel. Isr. J. Plant Sci, 43: 249-258.

Saha, P., Mohiuddin, A.K.M. and Shohael, A.M., 2015. In vitro Regeneration of Grass Pea (Lathyrus sativus L.). Jahangirnagar University J. Biol. Sci. 4(2): 1-8.

Sridhar, S., Mohan, C., Ramenna, M. and Reddy, K., 2015. Somatic Embryogenesis from Leaf and Internode Explants of Lathyrus sativus L. Int. J. Pure App. Biosci. 3 (2): 212-217.

Tripathy, S.K., Ranjan, R., Lenka, D., Mohapatra, B.R. and Pal, S., 2013. Somatic embryogenesis from in vitro cultured internode explants in grass pea (Lathyrus sativus L.). International Research Journal of Plant Science (ISSN: 2141-5447) Vol. 4(1) pp. 19-24.

Urga, K., Fite, A., Kebede, B., 1995. Nutritional and antinutritional factors of grasspea (Lathyrus sativus) germplasms. Bull. Chem. Soc. Ethiopia 9: 9-16.

Submitted: 16.05.2018

Accepted: 10.06.2018 